\title{
Association of Insulin Receptor Substrate-2 Gene Polymorphism with Ovarian Cancer
}

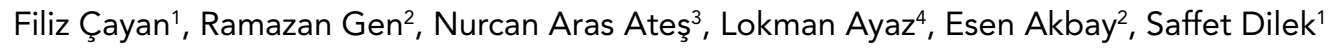 \\ ${ }^{1}$ Department of Obstetrics and Gynecology, Faculty of Medicine, Mersin University, Mersin, Turkey \\ ${ }^{2}$ Department of Internal Medicine, Faculty of Medicine, Mersin University, Mersin, Turkey \\ ${ }^{3}$ Department of Medical Biology and Genetics, Faculty of Medicine, Mersin University, Mersin, Turkey \\ ${ }^{4}$ Department of Biochemistry, Faculty of Medicine, Mersin University, Mersin, Turkey
}

\section{ABSTRACT}

Objective: The insulin receptor substrate (IRS) proteins have been implicated in contributing to all stages of tumorigenesis in many cancers, from initiating events to metastatic progression. In this study, we aimed to evaluate the association of IRS-2 gene polymorphism with ovarian cancer.

Material and Methods: The study group consisted of 185 women: 45 women with ovarian cancer and 140 control subjects. All the patients with ovarian cancer were primarily treated by surgical intervention. Genetic polymorphism of IRS-2 G1057D was detected by using polymerase chain reaction (PCR)based restriction fragment-length polymorphism (RFLP).

Results: For IRS-2 G1057D polymorphism, the frequencies of GG, GD and DD genotypes were $60 \%, 33.3 \%$, and $6.7 \%$, respectively in the ovarian cancer cases and $53.6 \%, 38.6 \%$ and $7.9 \%$ in controls. The risk for ovarian cancer was not significantlydifferent in the individuals with the IRS-2 DD genotype compared to the GG genotype (95\% Cl: 0.203-3.04, P: 0.787). Also, there was no association between carriage of the D allele and ovarian cancer risk. We found no significant difference between the genotypes in the ovarian cancer group and control group (P:0.545).

Conclusion: These results do not support an association between carriage of the G1057D variant of IRS-2 gene and ovarian cancer.

Key Words: Insulin receptor substrate-2 gene polymorphism, ovarian cancer, G1057D variation

Received: 10.09.2009 Accepted: 05.10.2009

\section{Introduction}

Insulin receptor substrate (IRS) molecules are distinctive adaptor proteins capable of integrating and coordinating cytoplasmic and nuclear signals from multiple signaling cascades, which are important during normal development and tumorigenesis. The IRS protein family contains six (IRS 1 to 6) structurally related intracellular signaling adaptor proteins. While IRS-1 and IRS-2 are widely expressed, the other members of the IRS family show limited species or tissue-restricted expression (1, 2).

Although IRS-1 and IRS-2 are homologous, they have divergent roles in metabolism. IRS-1 shows its greatest effect in adipose tissue and muscle. In contrast, IRS-2 is essentially localized in the ovary, liver, and pancreas. IRS-2 is expressed in a number of ovarian cell types and plays critical roles in ovarian function by regulating key components of the cell proliferation and differentiation (3-5). The IRS-2 gene is localized on chromosome 13q34 and the common IRS2 variant, a Gly to Asp change at codon 1057 (G1057D), has been associated with insulin sensitivity and mediates interaction with downstream signaling molecules (6-8).

Epithelial ovarian cancer is one of the most lethal gynecological malignancies and about two thirds of the patients are diagnosed in advanced stages (9). However, the biological and molecular basis of ovarian cancer is not understood completely. Since insulin receptor signaling regulates female reproductive function acting in the ovary, it is highly plausible that IRS-2 gene polymorphism may play a role in the development of ovarian cancer. Based on the previous studies, we aimed to investigate the association of the IRS-2 G1057D gene polymorphism with ovarian cancer.

\section{Materials and Methods}

The study group was composed of 45 women who were operated on for ovarian cancer between 2006 and 2008. The control group included randomly selected 140 healthy women attending our clinic for routine gynecologic examination during the same period, who were matched for age, and had normal cytological and ultrasound findings and tumor marker panel. A written informed consent was obtained from all the women, and the study protocol was approved by the Medical Ethics Committee at the University of Mersin School of Medicine, and conformed to the ethical guidelines of the 1975 Helsinki declaration. 
All patients in the study group underwent appropriate surgical exploration as suggested by FIGO, (10) and histopathological examination was performed under the guidance of WHO (11) Demographic characteristics including age at diagnosis, height, weight, reproductive and previous obstetric history were assessed in all the women. Body mass index (BMI) was calculated as weight $(\mathrm{kg})$ divided by the square of the height. The patients and control subjects were from the same geographic region (southern Turkey) and of the same ethnic origin (Turkish-white). For this reason race was not considered in the statistical analyses.

\section{DNA Extraction and Genotyping of IRS-2}

Heparinized venous blood samples were collected from women in the ovarian cancer and control groups. Immediately after collection, whole samples were stored at $+4^{\circ} \mathrm{C}$ until use. Genomic DNA was extracted from circulating leukocytes by the High Pure PCR template preparation kit (Roche diagnostics, GmbH, Mannheim, Germany) following manufacturer instructions. A polymerase chain reaction (PCR)-based restriction fragment-length polymorphism (RFLP) method was used to genotype IRS-2 G1057D polymorphism, which removes the Hae II restriction enzyme site. The PCR was performed in a 25 $\mu$ l volume containing $20 \mathrm{ng}$ genomic DNA, 10XPCR buffer with $1.5 \mathrm{mM} \mathrm{MgCl}, 0.25 \mathrm{mM}$ dNTPs, 10\% Dimethylsulphoxide, 0.5 units of Taq polymerase (Fermantas, $\mathrm{MBI}$ ), and 5 pmol of each primers IRS-2F (5' GCT CCC CCA AGT CTC CTA A $\left.3^{\prime}\right)$ and IRS-2R ( $5^{\prime}$ CTC AGC CTC TTC ACG CCC $\left.3^{\prime}\right)$. The PCR thermal cycling conditions were an initial melting period at $95^{\circ} \mathrm{C}$ for $2 \mathrm{~min}$; then 35 amplification cycles of $95^{\circ} \mathrm{C}$ for $45 \mathrm{~s}, 62^{\circ} \mathrm{C}$ for $45 \mathrm{~s}$ and $72^{\circ} \mathrm{C}$ for $45 \mathrm{~s}$; and a 7 -min extension step at $72^{\circ} \mathrm{C}$. The PCR products were checked on a $1.5 \%$ agarose gel for the assay completion and then the PCR products of 375 base pair (bp) were digested with restriction enzyme Hae-ll by overnight incubation at $37^{\circ} \mathrm{C}$. The digestion products were electrophoresed on $3 \%$ agarose gel and visualized by staining with ethidium bromide and evaluated using the gel documentation system (Vilber-Lourmat, Cedex, France).

\section{Statistical Analysis}

A case-control study was performed and the $\chi^{2}$ test was used to compare genotype frequency of the IRS- 2 gene polymorphism between ovarian cancer patients and controls. The association between IRS-2 polymorphisms and ovarian cancer patients was modeled through binary logistic regression analysis, and OR and 95\% confidence interval $(\mathrm{Cl})$ were calculated to compare ovarian cancer risk among genotypes. The characteristics of women in both groups were compared with the Student's t-test. The test for Hardy-Weinberg equilibrium was conducted by comparing observed versus expected genotype frequencies using a $\chi^{2}$-test. All values are represented as mean and standard deviation (SD). A p value less than 0.05 was considered as significantly different. The software used for the calculation was the SPSS version 11.5 (SPSS Inc., Chicago, IL).

\section{Results}

Table 1 summarizes the distribution of ages, BMI and parity of the groups. The mean age of the women was $52.0 \pm 12.74$ years (range, 30 to 78 years) in the ovarian cancer group and $53.5 \pm 15.2$ (range, 18 to 88 years) in the control group. The mean age, parity, and BMI did not significantly differ between the groups ( $p>0.05)$.

As shown in Table 2, the frequencies of GG, GD and DD genotypes were $60 \%, 33.3 \%$, and $6.7 \%$ in the ovarian cancer cases and $53.6 \%, 38.6 \%$, and $7.9 \%$ in the controls. We did not find any significant difference between the genotypes in the groups (P: 0.787). The frequency of $D$ allele was 0.233 for cases and 0.271 for controls. There was no difference between cases and controls in the frequency of $G$ and $D$ alleles ( $P ; 0.545$ Table 2). Regarding both groups (controls and patients with ovarian cancer); the distribution of IRS-2 genotypes was in the Hardy-Weinberg equilibrium $(p=0.957, p=0.919$, respectively).

\section{Discussion}

The insulin receptor substrates are cytoplasmic signaling molecules that mediate the effects of insulin, insulin-like growth factor-1, and other cytokines by acting as a molecular adaptor between diverse receptor tyrosine kinases and downstream effectors. Insulin and IGF initiate the tyrosine phosphorylation of intracellular IRSs by activated receptors. Genetic polymorphism located close to the tyrosine phosphorylation sites of the IRS genes, may cause a change in the tertiary structure of these proteins and may result in impaired signaling $(6,12-14)$. Since IRSs are involved in the effects of the IGFs, insulin, growth hormones, interleukins, and interferons, IRS gene polymorphism may contribute to the promotion of tumorigenesis by these mitogens.

Table 1. Demographic characteristics of the subjects

\begin{tabular}{|lccc|}
\hline & $\begin{array}{c}\text { Ovarian cancer } \\
(\mathbf{n}=45)\end{array}$ & $\begin{array}{c}\text { Control } \\
(\mathbf{n}=140)\end{array}$ & $\begin{array}{c}\mathbf{p} \\
\text { value }\end{array}$ \\
\hline Mean age (years) & $52.0 \pm 12.74$ & $53.5 \pm 15.2$ & 0.610 \\
Parity & $2.28 \pm 1.14$ & $2.43 \pm 1.07$ & 0.410 \\
$\mathrm{BMl}\left(\mathrm{kg} / \mathrm{m}^{2}\right)$ & $27.14 \pm 4.68$ & $27.37 \pm 3.63$ & 0.730 \\
\hline n: number of sample, p: values of significance & with difference of each group \\
BMl=body mass index & & \\
Note that values are given as the mean $\pm \mathrm{SD}$ & & \\
\hline
\end{tabular}

Table 2. IRS-2 genotypes and the risk of developing ovarian cancer

\begin{tabular}{|lcccc|}
\hline \multicolumn{3}{c}{ Patients } & \multicolumn{3}{c|}{ Control } \\
\hline Variable & $\mathbf{n}(\%)$ & $\mathbf{n}(\%)$ & OR $^{\ddagger}$ & $95 \% \mathbf{C l}$ \\
\hline Genotype & & & & \\
GG & $27(60.0)$ & $75(53.6)$ & 1 (reference) \\
GD & $15(33.3)$ & $54(38.6)$ & 0.77 & $0.37-1.58$ \\
DD & $3(6.7)$ & $11(7.9)$ & 0.75 & $0.203-3.04$ \\
Allele & & & & \\
G & $69(76.7)$ & $204(72.9)$ & 1 (reference) \\
D & $21(23.3)$ & $76(27.1)$ & 0.81 & $0.46-1.42$ \\
\hline
\end{tabular}

(n:) Number of observation, (OR:) odds ratio, (Cl:) confidence interval. Statistical analysis was performed by using the binary logistic regression analysis and Chisquare $\left(\chi^{2}\right)$ 
A number of additional surface receptors also utilize the IRS proteins as signaling intermediates. Receptors that signal through the IRS proteins include other growth factor/hormone receptors such as the growth hormone, leptin, vascular endothelial growth factor (VEGF), cytokine receptors including the IL-2, IL-4, IL-7, IL-9, IL-13 and IL-15 receptors, interferon receptors and members of the integrin adhesion receptor family. These disparate receptors regulate many different cellular functions and are expressed in distinct cell types. However, one common function that many of these receptors share is their potential role in the pathogenesis of tumorigenesis.(15-18)

In addition to their role as scaffolding proteins in the cytoplasm, IRSs are able to translocate into the nucleus and regulate gene transcription. While IRSs have been found to be oncogenic, they are also required for the transforming ability of numerous other oncogenes. They directly bind, interact, and cooperate with numerous other oncogens including JCV T-antigen, SV40T antigen, ret oncoprotein, and the ETV6-NTRK3 translocation oncoprotein. These known oncogenes are dependent on IRS tyrosine phosphorylation for mitogenic and transforming activity $(19,20)$.

Up to date, many studies have focused on the effect of IRS-1 in carcinogenesis, but few have addressed IRS-2. Most of our knowledge on the association of IRS-2 protein with tumorigenesis has been provided from invivo mouse model studies. IRS-2-deficient PyV-MT-derived mammary tumor cells are significantly more sensitive to serum deprivation-induced apoptosis than wildtype tumor cells, and IRS- $2^{-/-}$tumors also have a higher in situ level of apoptosis (15). Therefore, IRS-2 has been implicated in promoting tumor cell survival, which is likely to contribute to its role in tumor progression.

In recent reports, IRS-2 expression has been linked to specific cancers, such as breast cancer, hepatocellular carcinoma, pancreatic cancer, and colorectal cancer $(3,21-24)$. Slattery et al. found that a variant of IRS-2 was associated with colon cancer risk and the IRS-2 GD genotype reduced the risk of colon cancer (3). However, no association has been detected in studies of prostate cancer (25). To our knowledge, there has been no study investigating the role of IRS-2 gene polymorphism in gynecological cancers to date. Neganova et al investigated ovarian function in a novel IRS-2 global null mouse line, and they found reduced follicle size, increased numbers of atretic follicles, impaired oocyte growth and antral cavity development in IRS-2 null ovaries (5). Similarly, a recent study demonstrated that IRS-2 null female mice have small anovulatory ovaries, and reduced follicle number (2). In the present study, we observed that the frequencies of GG, GD and DD genotypes were $60 \%, 33.3 \%$, and $6.7 \%$, respectively in the ovarian cancer cases and $53.6 \%, 38.6 \%$, and $7.9 \%$, respectively in the controls $(p>0.05)$. However, we could not find any significant difference between the genotypes in the groups. Since the etiology of ovarian cancer appears to involve a complex interplay of multiple genetic, environmental, and immunologic factors, single gene polymorphism may not be sufficient to explain the pathogenesis of the disease. Moreover, focusing on a disease pathway, rather than isolated genetic polymorphisms, may provide more information on the importance of the pathway and the etiology of the disease.
In summary, there are many studies that provide clues to the potential role of IRSs in tumorigenesis. However, we could not find an association between the G1057D variant of IRS-2 gene and ovarian cancer in this population. A major limitation of this study is the modest sample size, and larger studies are needed to establish clearly the function of IRS proteins in human cancer.

\section{Conflict of Interest}

No conflict of interest was declared by the authors.

\section{References}

1. Dearth RK, Cui X, Kim HJ, Hadsell DL, Lee AV. Oncogenic transformation by the signaling adaptor proteins insulin receptor substrate (IRS)-1 and IRS-2. Cell Cycle 2007;6:705-13.

2. Burks DJ, Font de Mora J, Schubert M, Withers DJ, Myers MG, Towery $\mathrm{HH}$ et al. IRS-2 pathways integrate female reproduction and energy homeostasis. Nature 2000;407:377-82.

3. Slattery ML, Samowitz W, Curtin K, Ma KN, Hoffman M, Caan B et al. Associations among IRS1, IRS2, IGF1, and IGFBP3 genetic polymorphisms and colorectal cancer. Cancer Epidemiol Biomarkers Prev 2004;13:1206-14.

4. Gibson SL, Ma Z, Shaw LM. Divergent roles for IRS-1 and IRS-2 in breast cancer metastasis. Cell Cycle 2007;6:631-7. [CrossRef]

5. Neganova I, Al-Qassab H, Heffron H, Selman C, Choudhury Al, Lingard SJ et al. Role of central nervous system and ovarian insulin receptor substrate 2 signaling in female reproductive function in the mouse. Biol Reprod 2007;76:1045-53. [CrossRef]

6. White MF. IRS proteins and the common path to diabetes. Am J Physiol Endocrinol Metab 2002;283:413-22.

7. Lautier C, El Mkadem SA, Renard E, Brun JF, Gris JC, Bringer J et al. Complex haplotypes of IRS2 gene are associated with severe obesity and reveal heterogeneity in the effect of Gly1057Asp mutation. Hum Genet 2003;113:34-43.

8. Mammarella S, Romano F, Di Valerio A, Creati B, Esposito DL, Palmirotta $R$ et al. Interaction between the G1057D variant of IRS-2 and overweight in the pathogenesis of type 2 diabetes. Hum Mol Genet 2000;9:2517-21. [CrossRef]

9. Rosen DG, Yang G, Liu G, Mercado-Uribe I, Chang B, Xiao XS et al. Ovarian cancer: pathology, biology, and disease models. Front Biosci 2009;14:2089-102.

10. FIGO. Annual report on the results of treatment in gynecologic cancer. Int J Gynecol Obstet 1989;28:189-93.

11. WHO classification of tumors, pathology and genetics, tumours of the breast and female genital organs. Eds: Tavassoli FA, Devilee P. In Chapter 4, Tumors of the uterine corpus. pp: 218. IARC press, Lyon 2000.

12. White MF. The IRS-signaling system: a network of docking proteins that mediate insulin and cytokine action. Recent Prog Horm Res 1998;53:119-38.

13. White MF. The insulin signalling system and the IRS proteins. Diabetologia 1997;40:2-17. [CrossRef]

14. Yamauchi T, Kaburagi Y, Ueki K, Tsuji Y, Stark GR, Kerr IM et al. Growth hormone and prolactin stimulate tyrosine phosphorylation of insulin receptor substrate- $1,-2$, and -3 , their association with p85 phosphatidylinositol 3-kinase (PI3-kinase), and concomitantly PI3-kinase activation via JAK2 kinase. J Biol Chem 1998;273:15719-26.

15. Nagle JA, Ma Z, Byrne MA, White MF, Shaw LM. Involvement of insulin receptor substrate 2 in mammary tumor metastasis. Mol Cell Biol. 2004;24:9726-35. [CrossRef]

16. Mardilovich K, Pankratz SL, Shaw LM. Expression and function of the insulin receptor substrate proteins in cancer. Cell Commun Signal 2009;7:14. [CrossRef] 
17. Platanias LC, Uddin S, Yetter A, Sun XJ, White MF. The type I interferon receptor mediates tyrosine phosphorylation of insulin receptor substrate 2. J Biol Chem 1996;271:278-82. [CrossRef]

18. Shaw LM. Identification of insulin receptor substrate 1 (IRS-1) and IRS-2 as signaling intermediates in the alphabbeta4 integrin-dependent activation of phosphoinositide $3-\mathrm{OH}$ kinase and promotion of invasion. Mol Cell Biol 2001;21:5082-93. [CrossRef]

19. Khalili K, Del Valle L, Wang JY, Darbinian N, Lassak A, Safak M et al. T-antigen of human polyomavirus JC cooperates withIGF-IR signaling system in cerebellar tumors of the childhood-medulloblastomas. Anticancer Res 2003;23:2035-41.

20. Lannon CL, Martin MJ, Tognon CE, Jin W, Kim SJ, Sorensen PH. A highly conserved NTRK3 C-terminal sequence in the ETV6NTRK3 oncoprotein binds the phosphotyrosine binding domain of insulin receptor substrate-1: an essential interaction for transformation. J Biol Chem 2004;279:6225-34.
21. Chan BT, Lee AV. Insulin receptor substrates (IRSs) and breast tumorigenesis. J Mammary Gland Biol Neoplasia. 2008;13:415-22. [CrossRef]

22. Dearth RK, Cui X, Kim HJ, Kuiatse I, Lawrence NA, Zhang X et al. Mammary tumorigenesis and metastasis caused by overexpression of insulin receptor substrate 1 (IRS-1) or IRS-2. Mol Cell Biol 2006;26:9302-14. [CrossRef]

23. Bergmann U, Funatomi H, Kornmann M, Beger HG, Korc M. Increased expression of insulin receptor substrate-1 in human pancreatic cancer. Biochem Biophys Res Commun 1996;220:886-90. [CrossRef]

24. Boissan $M$, Beurel $E$, Wendum D, Rey $C$, Lécluse $Y$, Housset $C$ et al. Overexpression of insulin receptor substrate-2 in human and murine hepatocellular carcinoma. Am J Pathol 2005;167:869-77. [CrossRef]

25. Neuhausen SL, Slattery ML, Garner CP, Ding YC, Hoffman M, Brothman AR. Prostate cancer risk and IRS1, IRS2, IGF1, and INS polymorphisms: strong association of IRS1 G972R variant and cancer risk. Prostate 2005;64:168-74. [CrossRef] 